Юлия Зеликова

\title{
КОНСТРУИРОВАНИЕ СТАРЕНИЯ: СЕКС И ИНТИМНОСТЬ В ПОЖИЛОМ ВОЗРАСТЕ
}

Статья посвящена изучению интимных и сексуальных отношений в пожилом возрасте. Дискурс о старении в современном обществе строится вокруг утверждения, что с возрастом снижаются способности, потребности и желания, в том числе сексуальные. Старение воспринимается обществом как поражение человека, как неспособность жить вне заданных характеристик возраста. Цель статьи - продемонстрировать ошибочность представлений о сексуальности в пожилом возрасте. Исследование исходит из конструктивистского похода, в рамках которого старение - это процесс, обусловленный социальными институтами. В фокусе исследования находятся общественные стереотипы о сексуальной жизни пожилых людей, нормы поведения, приписываемые обществом, и социальные ожидания, влияющие на личную интимную жизнь в пожилом возрасте. Эмпирической базой являются 18 нарративных интервью с людьми в возрасте от 65 лет до 81 года. Анализ интервью реконструирует сексуальные проблемы, с которыми сталкиваются люди пожилого возраста, позволяет увидеть их новый сексуальный опыт и понять, какой смысл они придают интимности и телесности. Особое внимание уделяется тому, как пожилые партнеры поддерживают отношения друг с другом. В статье показано, что в современной России конструирование пожилого возраста осуществляется, в частности, с помощью контроля над сексуальностью в форме отказа пожилым людям в праве на сексуальную активность. Интимность, телесность и сексуальность пожилых людей воспринимаются как отступление от нормы и несоответствие ожиданиям. Такое явление следует описывать как эйджизм, поскольку эти практики производят маргинализирующий и стигматизирующий дискурс в отношении пожилых людей.

Юлия Александровна Зеликова - к.с.н., доцент Северо-западного института управления РАНХиГС, Санкт-Петербург, Россия. Электронная почта: zelikova-ia@sziu.ranepa.ru 
Ключевые слова: критическая геронтология, интимность, сексуальность в пожилом возрасте, конструирование старения, нарративные интервью

DOI: 10.17323/727-0634-2018-16-1-125-140

\section{Введение}

Отсутствие интимных и сексуальных отношений в пожилом возрасте - один из широко распространенных стереотипов о старении. Более того, пожилой возраст часто конституируется как такой этап в жизни человека, в котором отсутствуют любовь и секс. Общество отказывает пожилым людям в способности к любовным переживаниям и сексуальной активности (Tetley et al. 2017).

В статье используются теоретические подходы и эмпирический материал для демонстрации ошибочности представлений о сексуальности в пожилом возрасте. Исследование показывает необходимость изучения смыслов и ценностей сексуальных отношений для пожилых людей. Анализ эмпирического материала позволяет выявить дискурсы и практики, которые создают стереотипы, стигматизирующие и маргинализирующие пожилых. Таким образом, отмечается дискриминационный характер этих дискурсов.

В 1978 г. Сьюзен Сонтаг (Sontag 1978) показала, что дискурс вокруг темы старения строится на утверждении того, что с возрастом снижаются способности, пропадают желания, утрачиваются навыки. Старение оценивается обществом как поражение человека, а успехом считается его/ее способность как можно дольше скрывать признаки преклонного возраста. Особенно это касается женщин. Эта работа вызвала большой интерес исследователей, изучающих возраст в рамках феминистской парадигмы (Hinchliff, Gott 2017). Они продемонстрировали ложность таких представлений о старости. Исследования свидетельствовали, что у пожилых людей есть свое понимание старения, они придают собственные значения возрасту, отличные от распространенных в обществе (Низамова 2016). В частности, такие темы как сексуальность, интимность, эмоциональность и чувственность невозможно одинаково оценивать в разные периоды жизненного цикла человека (Hinchliff, Gott 2017).

В российской социологии тема сексуальности привлекала внимание социологов, начиная с 1990-х гг. (Кон 2005; Темкина 2008). Однако сексуальность пожилых до сих пор остается практически без внимания (напр., Рогозин, Ипатова 2016). Мы вносим свой вклад в научные дискуссии о старении на российском материале. Нами используется подход к анализу возраста, в рамках которого старение - это процесс, сконструированный в условиях воздействия социальных институтов. Именно социальные институты приписывают для созданных категорий (таких как «молодость», «средний возраст» или «старость») нормы поведения, критерии успешности и социальные ожидания (Featherstone, Wernick 1995). Процесс со- 
циального конструирования категорий возраста рассматривается на трех уровнях. Государство и экономика (макроуровень) влияют на условия старения, хотя индивиды активно конструируют свой социальный мир через личные интеракции (микроуровень) и через институциальную структуру (мезоуровень).

Темы в изучении старения, которые рассматриваются с точки зрения социального конструктивизма, объединены в теорию, получившую название «критической геронтологии» (Estes 1999). Последняя рассматривает старение с точки зрения власти и контроля в обществе (Estes 1999; Phillipson 2006), которые касаются и позиции исследователя в отношении эмпирического материала, т.к. данные не могут быть отделены от теоретического подхода, интересов, ориентации и субъективных характеристик исследователя (Gubrium 1993).

\section{Медицинские исследования сексуальности пожилых}

Результаты большинства исследований, посвященных сексуальности пожилых и отношениям между ними в поздний период жизни, сводятся к тому, что их сексуальная активность снижается, появляется сексуальная неудовлетворенность и физическая слабость (Karraker et al. 2011). Важно отметить, что это понимание складывается в рамках медицинского дискурса, предполагающего проникающий секс как норму на протяжении всей жизни человека, что исключает из рассмотрения разнообразие сексуального опыта (DeLamater, Koepsel 2015). Тем не менее для пожилых людей может быть гораздо важнее эмоциональная близость, тактильные отношения и другие формы близости (Galinsky, Waite 2014; Hinchliff, Gott 2017).

Исследователи старения объясняют это тем, что до недавнего времени сексуальность и сексуальная активность рассматривалась с точки зрения теоретического подхода, фокусирующегося на влиянии медицинских, социальных и психологических факторов на сексуальность (Carpenter, DeLamater 2012). Логика этого подхода предполагала, что снижение с возрастом ментальных, физических и социальных ресурсов человека неизбежно ведет к изменению сексуальной активности. Исследования, выполненные в рамках этой парадигмы, демонстрируют, с какими сексуальными проблемами сталкиваются люди в пожилом возрасте. Но они не позволяют увидеть их новый сексуальный опыт и понять, какой смысл они сами придают интимности и телесности (Hinchliff, Gott 2017). Большинство исследований концентрируются на индивидуальном опыте и на индивидуальных переживаниях, не рассматривая партнерские отношения (DeLamater 2012; Gledhill, Schweitzer 2014).

Существуют многочисленные исследования, как можно с помощью медицинских препаратов продлить способность к проникающему сексу, как главной форме сексуальной близости. Но мало исследований о том, 
как меняется роль проникающего секса во взаимоотношениях (Tetley et al. 2017). Представленный нами анализ дает голос самим пожилым, чтобы восстановить те смыслы, которые они придают сексуальности. Это позволяет увидеть широкое разнообразие опыта за пределами узких рамок медицинских определений секса.

\section{Методология исследования}

Эмпирические данные включают 18 продолжительных (не менее двух часов) нарративных интервью с пожилыми людьми в возрасте от 65 лет до 81 года (10 женщин и 8 мужчин). Все информанты хорошо знакомы с автором исследования, осуществлявшим и функцию интервьюера. Это обстоятельство значительно облегчало производство и интерпретацию нарратива, так как между информантом и интервьюером установлен высокий уровень доверия, интервьюер знала биографический контекст информанта, имела возможность избегать травмирующих тем и не тратить время на уточняющие вопросы.

Тема интервью анонсировалась как разговор о старении, т.е. разговор о том, что в жизни человека меняется с возрастом, какой опыт при этом переживается, как происходит принятие возраста. Интервью проводились без предварительно сформулированных вопросов - задавалась тема разговора, следуя за нарративом информанта. Тема сексуальности и интимности возникала либо спонтанно, либо провоцировалась интервьюером фразой: «Давайте поговорим о сексе». После этого разговор начинал строится вокруг сексуальных отношений информанта после 60 лет, взаимоотношений с партнерами, изменений, связанных с формой, значением и ценностью сексуальных отношений. Таким образом, информанты говорили не только о существующих интимных отношениях (в момент интервью они были не у всех), но и ретроспективно вспоминали сексуальную жизнь после 60 лет.

Все женщины, участвующие в исследовании, имеют высшее образование, продолжали работать: двое преподавателями в университетах (информанты в возрасте 65 и 67 лет), библиотекарем (69 лет) и спортивным тренером (71 год). Из оставшихся шести женщин, трое в прошлом были инженерами (81 год, 78 лет и 75 лет), врачом (73 года), школьным учителем (72 года) и технологом пищевой промышленности (75 лет). Из восьми мужчин, участвующих в исследовании, продолжали трудиться четверо: двое - инженерами (78 лет и 76 лет), преподавателем университета (80 лет) и водителем (69 лет). Из не работавших в момент интервью мужчин двое занимали руководящие должности в строительстве (72 года и 75 лет), один работал главным конструктором на предприятии ВПК (75 лет) и один в прошлом военный (70 лет).

Из десяти женщин, включенных в выборку, трое на момент исследования состояли в браке. Это информанты в возрасте 78 лет, 75 лет и 73 года. 
Они имели с супругом длительные (более 45 лет) отношения. Еще четыре женщины (65 лет, 75 лет, 69 лет и 72 года) - вдовы, у которых также в прошлом опыт длительных супружеских отношений. Кроме них в выборку включены еще три женщины, которые имели опыт супружеских отношений только в молодые годы, более 40 лет назад. Две из десяти женщин не имели детей (69 лет и 75 лет). Еще две женщины имели детей, но не имели внуков (81 год и 75 лет). Все остальные имели и детей, и внуков. Все интервьюируемые мужчины имели длительный опыт супружеских отношений. У всех есть и дети, и внуки. На момент исследования пять из них состояли в браке, двое - были вдовцами, не вступившими в повторный брак (76 лет и 75 лет), и один человек развелся более 20 лет назад (72 года).

В ходе анализа интервью были выделены четыре основные темы (ср., Здравомыслова, Темкина 2000), которые относятся к дискурсу, производящему стигматизирующие в отношении пожилых смыслы. Первая тема здоровье, иллюстрирует, как здоровье влияет на изменение сексуальных отношений и как эти изменения воспринимаются респондентами. Вторая связана с изменением сексуальных практик и отношений между партнерами в пожилом возрасте. Третья тема касается гендерных различий в процессе старения. И четвертая - влияние общественного мнения и стереотипов на сексуальную жизнь пожилых людей.

\section{Сексуальность пожилых людей В контексте здоровья и болезни}

Исследования сексуальности пожилых, проведенные в странах Европы и США (Tetley et al. 2017) показывают, что проблемы со здоровьем, хронические заболевания, прием медикаментов упоминаются пожилыми людьми, как наиболее частая причина снижения их сексуальной активности. Результаты этого исследования позволяют сделать несколько иные выводы. Проблемы со здоровьем воспринимаются пожилыми людьми как естественные условия старения, обстоятельства, с которыми постоянно живут, и они не готовы объяснять изменения в своей жизни проблемами со здоровьем:

Конечно, с возрастом у всех есть какие-то болезни. Нет здоровых людей в моем возрасте. Но у меня все, как говорится, согласно паспорту. Поэтому я считаю, что у меня со здоровьем все в порядке. Для меня проблема - это тело. Мне оно не нравится. Кожа на руках висит. Вены. Живот. С мужем все было нормально. Он мне всегда говорил, что все в порядке, все отлично. Нужно, чтобы доверие было, чтобы близость была, невозможно просто так снять одежду (женщина, 67 лет).

Приведенная цитата показывает, что проблематичным представляет не состояние здоровья, а стареющее тело, стереотип, что для секса надо соответствовать канонам красоты, что секс существует только для молодых и привлекательных. Эти стереотипы создают барьеры для интимных 
взаимоотношений. Женщина боится критики со стороны партнера, нуждается в поддержке и одобрении.

Этот пример демонстрирует еще одну проблему пожилых, особенно женщин: когда оставшись в одиночестве после длительных супружеских отношений, он возвращается в ту часть своего жизненного цикла, в которой сексуального опыта еще не было. Сложно перенести свой предыдущий сексуальный опыт на отношения с новым партнером, словно все начинается сначала. Во всяком случае, по эмоциональным переживаниям это очень похоже на неуверенную подростковую сексуальность. В своем отношении к сексу пожилые люди похожи на подростков, которые еще не начали сексуальную жизнь. Причина также находится в том значении, которое пожилые люди придают интимным отношениям:

Мы в санатории познакомились. Ходили за руку как дети. И были счастливы. Вот он меня касался, и у меня сердце останавливалось. И я считаю, что это больше, чем секс. Секс мне часто приносил проблемы, унижения. А сейчас - это чистая радость. В первый раз, когда я влюбилась, я также чувствовала. И секса тогда тоже не было (женщина 81 год).

Мужчины отмечали в интервью, что после сексуальной близости часто чувствуют ухудшение состояния здоровья. Но они также воспринимают это скорее, как возрастную норму, чем ограничение, которое накладывает состояние здоровья на сексуальную жизнь:

У меня проблемы со здоровьем уже давно. Я привык. Ну, есть какие-то ограничения. Ну, так что. Если возникает желание, если я вижу, что жена настроена... Ну, пусть потом не очень себя чувствуешь. Мало ли от чего можно плохо себя чувствовать? Но ведь близость важна. Пока возможность есть, я не буду из-за здоровья себя ограничивать (мужчина, 69 лет).

В данном случае возможность вести активную сексуальную жизнь важнее самочувствия. Он утверждает, что скорее готов пожертвовать здоровьем, чем отказаться от сексуальной активности. Российские демографы и исследователи здоровья отмечают, что для российских мужчин свойственно пренебрежительное отношение к своему здоровью (Вишневский 2014). Здоровье для них - это в определенном смысле разменная монета, которой они платят за различные удовольствия. Сексуальная активность, способность к сексуальной близости входит в перечень того, ради чего можно рисковать здоровьем, как показывает цитата выше.

Исследование выявило и такие случаи, когда состояние здоровья действительно серьезно ограничивает или исключает сексуальную активность, по крайней мере, на время:

После инфаркта жена за меня боится. Мы стали спать в разных комнатах. Но зато каждое утро встречаемся, как будто давно не виделись. Обнимаемся, целуемся, радуемся. Конечно, это не секс. Но меня это как-то 
воодушевляет. Иногда я думаю, что это важнее, чем секс в том смысле, в котором мы все о нем думаем. Потому что вот без такого секса я уже пару лет живу. А вот без этих наших обниманий, без этих шуточек, без этих прижиманий, как жить я не представляю (мужчина, 72 года).

В ситуации, когда здоровье ограничивает сексуальную активность, супруги интуитивно находят интимные практики, которые приносят положительные эмоции. В данном случае болезнь не оценивается как проблема, которая снижает качество жизни. Это условия, в которых стали возможны новые эмоции, новые переживания. Эти эмоции воспринимаются как более важные, чем способность к физической близости.

Для пожилых людей сексуальная активность гораздо сильнее связана с наличием любовных, романтических отношений, чем для людей молодого и среднего возраста. Именно отсутствие отношений, отсутствие чувств респонденты определяют как причину отказа от сексуальной активности:

У меня последний раз был роман 5 лет назад. Мне было тогда 72 года. И все, больше не хочу. Может это старость, может здоровье, может еще что. Но, не хочу. Раньше все просто было. Мужиков всегда полно было. Но, с возрастом - все. Да, не потому что что-то болит. Это-то все ерунда. Болит и болит. Оно всегда болит, что не делай. Не хочется просто так. А чувств пока нет (женщина, 78 лет).

Для молодых людей и людей среднего возраста причины для того, чтобы заниматься сексом, весьма разнообразны. Любовь в этом списке только одна из причин. Для информантки чувства - это главная причина сексуальных отношений, если они есть, то не имеет значение возраст и состояние здоровья. Возможность проявить и показать любовь - это возможность доставить удовольствие.

Несмотря на то, что здоровье является важным фактором сексуальной активности, пожилые люди не рассматривают его как существенное ограничение своей сексуальной жизни. Они заменяют сексуальные практики на иного рода интимные и тактильные практики, сопровождающиеся большой эмоциональностью. Информанты готовы терпеть некоторые проблемы со здоровьем, но не отказываться от интимной близости. Они находят для сексуальности новые смыслы и начинают новую сексуальную жизнь на очередном этапе жизненного цикла. Состояние здоровья при этом рассматривается как некое структурное условие, важное, но не определяющее качество интимной жизни.

\section{Изменение сексуальных практик с партнером в пожилом возрасте}

Результаты многих исследований показывают, что с возрастом проникающий секс уступает место другим сексуальным практикам (Gott, Hinchliff 2003). Успешность сексуальной жизни в пожилом возрасте 
во многом зависит от того, насколько партнеры готовы к этому. Наш анализ дает основания предполагать, что в России эта проблема может быть еще более явно выражена. Во-первых, у людей старшего поколения отсутствует культура обсуждать сексуальные отношения, говорить о своих желаниях и о своей неудовлетворенности. Во-вторых, мужчины часто приравнивают проникающий секс к сексуальным отношениям и не готовы участвовать в другого рода сексуальных практиках:

Я пытаюсь сказать, что необязательно, чтобы был такой секс. Можно же по-другому. Пыталась ему показать. А он говорит: «Ну, это все ты можешь сделать себе сама. Зачем тебе я?» (женщина, 69 лет).

Когда партнеры рассматривают сексуальные отношения с эгоистической точки зрения, то диалог о сексе невозможен, а отношения становятся проблематичными. Необходимы взаимные уступки и взаимопонимание:

Это раньше я говорила хочу-не хочу. А сейчас, если вдруг что получается, то уже никаких отказов. Это очень важно и для него, и для меня. Гораздо стала терпимее. И я вижу, как для него это важно (женщина, 73 года).

В ходе интервью респонденты подчеркивали, что ценность секса в супружеских отношениях с возрастом меняется, а ценность любви - возрастает. Поэтому большое значение придается любым формам интимности и тактильности, например, прикосновениям и поцелуям:

Когда люди вместе почти 50 лет, и им все еще хочется касаться друг друга, это очень дорого стоит. Это в сто раз сложнее, чем иметь в молодости 100 любовниц или любовников (женщина, 78 лет).

Пожилые супружеские пары оценивают длительность счастливого брака как большое достижение. При этом счастливый брак от несчастливого они отличают степенью практикуемой тактильности. Информанты-женщины иногда отмечали, что отсутствие проникающего секса сделало их супружеские отношения более спокойными и счастливыми. Вместе с сексом из отношений ушли ревность, обиды, зависимость от желания партнера, чувство унижения и неудовлетворенности:

После того, как секс у нас прекратился, все стало гораздо лучше. Ничего не ждешь. Не волнуешься, почему он не хочет заниматься со мной сексом. Есть ли у него кто-то другой. Просто прижимаешься и чувствуешь радость (женщина, 75 лет).

Мужчины более болезненно переживают изменения, связанные со способностью к физической близости. Они даже готовы отказаться от отношений с женщиной, если в этих отношениях нет проникающего секса:

Как я могу жениться. Я же в постели мало чего могу. Жена мне прощала, если что. Поэтому иногда что-то получалось. Но, это же надо 
доверие и терпение иметь большое. Это же надо всю жизнь прожить с человеком. Это же все не просто так (мужчина, 75 лет).

Стереотипы, связанные с тем, что проникающий секс - это единственно возможный вид сексуальной активности, без которого невозможны близкие отношения, обрекают пожилых людей на одиночество. Переоценка важности проникающего секса в пожилом возрасте ведет к неуверенности в себе, потере смысла сексуальности. Мы видим, как удовольствие и радость исчезают из разговора о сексе.

В то же время, исследование позволило выявить другое отношение к сексуальности в поздний период жизни. Оно основано на понимании своих снижающихся способностей к проникающему сексу, на переосмыслении значения сексуальности и использовании других форм близости:

Не надо ни о чем волноваться. Не надо думать, что и как получится.

Надо хотеть доставить удовольствие. Не только себе, а ей. Это главное.

И все. И все получится. Руки же на месте и губы тоже (мужчина, 70 лет).

Старение приносит с собой определенные ограничения. В пожилом возрасте преимущество получают те, кто научился жить с этими ограничениями, кто не стремится воспроизводить практики более молодых. Вероятно, мужчинам сложнее принять эти ограничения, изменить свое отношение к сексу, перестроить взаимоотношения с партнерами. Им проще отказаться от отношений вообще, чем иметь отношения с женщиной без проникающего секса. Для женщин напротив - он утрачивает свою привлекательность. Увеличивается потребность в других формах интимности и близости, которые часто важнее для ощущения удовлетворенности, чем обычные практики секса.

\section{Гендерные различия сексуальности в пожилом возрасте}

Мужчины и женщины стареют по-разному. Общество предъявляет им разные требования, формирует разные стандарты поведения (Sontag 1978). В интервью информантки много говорили о том, что в России нет никакой инфраструктуры для пожилых: кафе, клубов, спортивных залов, где пожилые люди могли бы комфортно проводить свободное время, не сравнивая себя с людьми более молодого возраста и не соперничая с ними:

Когда я приезжаю к дочери в Америку, я чувствую себя женщиной. Я хожу развлекаться. Мне кажется, мужчины обращают на меня внимание. Здесь я чувствую себя бабушкой, у которой все в прошлом (женщина, 71 год).

Отсутствие инфраструктуры старения, а также моделей поведения для пожилых людей приводит к социальной эксклюзии. В России для пожилых женщин есть только одна роль - это роль бабушки. Женщины, у которых нет внуков переживают кризис идентичности. Роль бабушки 
им недоступна, других ролей общество не предлагает. В российском контексте, когда женщина теряет свою сексуальность, она теряет свою женственность, т. е. становится «бесполым существом»:

Мы не привыкли нравиться сами себе. Нам нужен мужчина. А мужчинам нравятся молодые. Вот мы и стараемся изо всех сил. А кто не выдерживает гонки, тот опускает руки, и превращается в теток, которые совсем за собой не следят. Нет секса. Нет мужчины. Зачем хорошо выглядеть? Можно позволить себе других удовольствий (женщина, 75 лет).

Общество вынуждает женщину скрывать свой возраст, общество призывает ее бороться со старостью. Но борьба с возрастом обречена на провал. Рано или поздно все сдаются. Для успешного переживания старения важно вовремя освободиться от этого давления - понять, что пожилой возраст приносит свободу:

Десять лет назад я очень переживала, что старею, что у меня морщины, седина. Я не хотела встречаться с людьми, которых знала в молодости. Не пошла на встречу со своей группой университетской. В зеркало не хотела смотреть. А сейчас мне наплевать. Я чувствую себя свободной. Это единственно хорошее, что есть в старости (женщина, 73 года).

Для женщин, которые состоят в счастливых супружеских отношениях, проблема идентичности менее актуальна. Они видят себя глазами своих партнеров, для которых они сексуально привлекательные женщины. Это и является основой их гендерной идентичности:

Пока был жив муж, у меня не было проблем. Я не чувствовала возраста. Он меня до последнего момента за задницу щипал. А сейчас я просто не могу. Вот у меня был юбилей. Я знала, что студенты готовят мне поздравления, что меня ждут. Но я не понимаю, что отмечать? Чему радоваться-то? Я чувствовала, что не могу, не хочу это отмечать. И именно в свой день рождения я заболела так, как давно не болела, и никуда не пошла (женщина, 65 лет).

Результаты исследования позволяют выделить и стратегию мужского поведения, которая в пожилом возрасте помогает поднять собственную самооценку и легче переживать процесс старения. Эта стратегия связана с созданием отношений с женщинами более молодого возраста: «Я не собираюсь встречаться с женщиной моего возраста. Я ищу женщину лет на 15-20 моложе» (мужчина, 72 года). Отношения с женщиной намного моложе себя в сознании мужчин являются свидетельством успешности и состоятельности. Общество поощряет такие связи, в отличие от обратной ситуации, когда женщина имеет отношения с мужчиной намного себя младше.

Следует отметить, что в реальной жизни пожилые мужчины часто вступают в отношения с ровесницами. Можно даже предположить, что это более распространенная ситуация, чем связь с молодыми женщинами. 
Но, если спросить мужчину о новой партнерше, то он, как правило, расскажет о женщине значительно моложе него. Таким образом, установка на связь с молодой женщиной - это скорее проекция, чем реальность, результат общественного давления и нежелание признать, что и пожилая женщина может быть сексуально привлекательна.

Гендерные стереотипы о старении дискриминируют пожилых женщин. Они отчуждают их от своего тела, разрушают их идентичность, а мужчин вынуждают вступать в очень уязвимые отношения с женщинами моложе себя.

\section{Сексуальная жизнь пожилых людей и социальный контроль}

Одна из наиболее часто встречающихся тем в интервью с пожилыми людьми - тема конфликта с общественным мнением, которое отказывает пожилым людям в способности к любви, сексу, романтическим отношениям и физическим удовольствиям. Этот отказ применяется к тем отношениям, которые формируются уже в пожилом возрасте. Когда пожилая пара, состоящая в длительных супружеских отношениях, демонстрирует свои чувства, это вызывает позитивную реакцию. Если отношения только начинаются, то партнеров подозревают в корысти, обмане или неспособности адекватно оценить свои чувства. Это отношение исходит от детей, друзей и посторонних людей:

В санатории я попросил себе отдельную комнату. Без соседей. В регистратуре удивились, зачем, говорят, вам. Я говорю, что хочу познакомиться с женщиной и пригласить ее к себе. А девушки так удивились. Сказали, что это не предусмотрено. Что комнаты рассчитаны либо на семью, либо на двоих (мужчина, 76 лет).

Организация пространства в учреждениях, предназначенных для одиноких пожилых людей, не предусматривает наличия личного пространства, так как сексуальность в этом возрасте не подразумевается вообще. Пожилые люди оказываются в унизительном положении, когда в заведениях, предназначенных для их отдыха, им запрещено иметь личную жизнь.

Наиболее серьезные конфликты по поводу личной жизни возникают у пожилых людей со своими взрослыми детьми:

Когда умерла моя жена, я познакомился с женщиной. Мне тогда было 72 года, а ей - 64 года. Моя жена долго болела, я очень устал. А эта женщина была такая веселая, ласковая, сексуальная. Я был счастлив. Хотел жениться. Но моя дочь сказала, что она подаст в суд и признает меня недееспособным. Она была абсолютно уверена в том, что этой женщине нужна только моя квартира и дача. Она считала, что она меня спасает от хищницы. О том, что мы любим друг друга, она не хотела слышать (мужчина, 80 лет). 
Мы видим, что взрослые дети оставляют за собой право оценивать адекватность поведения своих родителей, наделять их поступки собственным смыслом, контролировать их поведение, ограничивать их действия. Это обрекает пожилых людей на страдания и одиночество. Они отказываются от отношений со своими партнерами, утрачивают доверие к детям, становятся замкнутыми и несчастливыми. Есть исследования, которые приходят к выводу, что количество родственных связей негативно влияет на удовлетворенность жизнью пожилых людей (Veenhoven 2000). В первую очередь это связано с социальным контролем со стороны родственников. В проведенных интервью есть иллюстрации и возможные объяснения для таких выводов.

Еще одной причиной конфликтов является представление детей о том, что свободное время пожилых родителей принадлежит внукам, так как роль бабушки или дедушки - единственная нормативная роль для этого возраста:

В молодости мы с мужем спали в одной комнате с ребенком. Сексом заниматься было сложно. Потом, я очень боялась забеременеть. Старалась ложиться спать, когда муж уже спит. Сейчас все гораздо проще. Как минимум, я не боюсь забеременеть и у меня есть своя квартира. Но, когда я говорю дочери, что не приеду к ней сидеть с внуками, так как ко мне придет мой друг, она злится. И всем своим друзьям говорит, что я сошла с ума на старости лет (женщина, 67 лет).

Этот пример также показывает неспособность людей старшего поколения говорить о сексе и о своей личной жизни. Мы видим, как в молодости женщина страдала от того, что не могла обсудить с мужем вопросы контрацепции и сексуальной неудовлетворенности. Сейчас она страдает от того, что не может обсудить с дочерью границы своего личного пространства и право на сексуальность.

Общественные стереотипы по отношению к пожилым людям можно оценить, как проявление эйджизма. Пожилые люди являются одной из самых уязвимых и бесправных социальных групп. Помимо иных обстоятельств, которые не обсуждались в этой статье, пожилые подвергаются социальной эксклюзии и с помощью социального контроля их жестко ограничивают в праве на личную жизнь, отрицая саму ее возможность.

\section{Заключение}

На поздней стадии жизненного цикла сексуальная активность людей сохраняется, хотя меняет формы, смыслы и значения. Снижение способности к проникающему сексу влечет за собой интерес к другим формам интимности и тактильности, но в то же время часто приводит к конфликтам с партнером.

В пожилом возрасте сексуальная близость приобретает новое значение, например, понимается как способ продемонстрировать свои чувства, 
спровоцировать положительные эмоции у партнера, оказать поддержку. Именно отсутствие любви, а не проблемы со здоровьем, назывались информантами как причина отказа от сексуальных отношений. Неспособность понять эти изменения, привыкнуть к новым формам сексуальности, нежелание обсуждать и искать новые смыслы отношений приводит к одиночеству, отказу от отношений и эксклюзии.

Гендерные различия в сексуальности пожилых в России воспроизводят сексизм. Так, существующее снисходительное отношение к сексуальным связям пожилых мужчин с женщинами, которые значительно моложе их, при осуждении таких отношений со стороны пожилых женщин. Общество формирует для пожилых женщин образ бабушки - модель, которая исключает сексуальность. А в противовес этой модели предлагается образ женщины без возраста, которая его скрывает и тратит ресурсы на поддержку молодости.

В России пожилой возраст понимается как возраст, в котором отсутствуют секс и интимность. Это конструирование происходит с помощью организации инфраструктуры, неприспособленной к потребностям пожилых людей, с помощью социального контроля и ограничения личного пространства. Важным институтом социального контроля над сексуальным поведением пожилых является семья, где взрослые дети приписывают себе право принимать решения за пожилых родителей, в том числе нужны ли им отношения с новыми партнерами. Такое понимание пожилого возраста дискриминирует пожилых, то есть приводит к эйджизму.

Эйджизм проявляется во многих социальных сферах: дискриминация на рынке труда, неразвитость инфраструктуры досуга, отсутствие качественной институализированной заботы, ограничение социального гражданства. Конструирование пожилого возраста через механизмы контроля над сексуальностью и отказ в праве на сексуальную активность - это тоже проявление эйджизма. Эти практики производят маргинализирующий и стигматизирующий дискурс по отношению к пожилым людям, которому они не могут сопротивляться.

\section{Список источников}

Вишневский А. (2014) Смертность в России: Несостоявшаяся вторая эпидемологическая революция. Демографическое обозрение, 4 (1): 2-36.

Здавомыслова Е.А., Темкина А. А. (2000) Социология гендерных отношений и гендерный поход в социологии. Соииологические исследования, (12): 33-46.

Кон И. (2005) Сексуальная культура в России: Клубничка на березке. М.: Айрис-пресс.

Низамова А. (2016) Активное долголетие и внешний вид: как теоретическая концепция регулирует самовосприятие в старшем возрасте? Журнал исследований социиальной политики, 14 (4): 569-582. 
Рогозин Д.М., Ипатова А.А. (ред.) (2016) Старикам тут место: социальное осмысление старения. М.: Институт социологии РАН.

Темкина А. (2008) Сексуальная жизнь женщины: между подчинением и свободой. СПб.: Издательство Европейского университета в Санкт-Петербурге.

Carpenter L., DeLameter J. (eds.) (2012) Sex for Life: From Virginity to Viagra, How Sexuality Changes Throughout Our Lives. New York: New York University Press.

DeLamater J. (2012) Sexual Expression in Later Life: A Review and Synthesis. Journal of Sex Research, 49 (2/3): 125-141.

DeLamater J., Koepsel E. (2015) Relationships and Sexual Expression in Later Life: A Biopsychosocial Perspective. Sexual and Relationship Therapy, 30 (1):37-59.

Estes C.L. (1999) Critical Gerontology and the New Political Economy of Aging. In: M. Minkler, C. L. Estes (eds.) Critical Gerontology: Perspectives from Political and Moral Economy. New York: Baywood Publishing: 17-35.

Featherstone M., Wernick A. (eds.) (1995) Images of Ageing: Cultural Representations of Later Life. London: Routledge.

Galinsky A. M., Waite L. J. (2014) Sexual Activity and Psychological Health as Mediators of the Relationship Between Physical Health and Marital Quality. Journals of Gerontology: Psychological Sciences and Social Sciences, 69B (3): 482-492.

Gledhill S., Schweitzer R.D. (2014) Sexual Desire, Erectile Dysfunction and the Biomedicalization of Sex in Older Heterosexual Men. Journal of Advanced Nursing, 70 (4): 894-903.

Gott M., Hinchliff S. (2003) Sex and Ageing: a Gendered Issue. In: S. Arber, K. Davidson, J. Ginn (eds.) Gender and Ageing: New Directions. Buckingham: Open University Press: 63-78.

Gubrium J.F. (1993) Voice and Context in a New Gerontology. In: T. Cole, W. A. Achenbaum, P. Jakobi, R. Kastenbaum (eds.) Voices and Visions of Aging: Toward a Critical Gerontology. New York: Springer: 46-64.

Hinchliff S., Gott M. (2017) Challenging Social Myths and Stereotypes of Women and Aging: Heterosexual Women Talk About Sex. Journal of Women and Aging, 20 (1): 65-81.

Karraker A., DeLamater J., Schwartz C. R. (2011) Sexual Frequency Decline from Midlife to Later Life. Journals of Gerontology: Psychological Sciences and Social Sciences, 66B (4): 502-512.

Phillipson C. (2006) Aging and Globalization: Issues for Critical Gerontology and Political Economy. In: J. Baars, D. Dannefer, C. Phillipson, A. Walker (eds.) Globalization and Inequality. New York: Baywood Publishing:43-58.

Sontag S. (1978) The Double Standards of Aging. In: V. Carver, P. Liddiard (eds.) An ageing population. Milton Keynes: Open University Press: 72-80.

Tetley J., Lee D. M., Nazroo J., Hinchlif S. (2017) Let's Talk about Sex - What do Older Men and Women Say about Their Sexual Relations and Sexual Activities? A Qualitative Analysis of ELSA Wave 6 data. Ageing \& Society, (4): 1-25.

Veenhoven R. (2000) Well-Being in the Welfare State: Level not Higher, Distribution not More Equitable. Journal of Comparative Policy Analysis, (2): 91-125. 
Julia Zelikova

\section{THE CONSTRUCTION OF AGING IN CONTEMPORARY RUSSIA: SEX AND INTIMACY IN THE LATE LIFE PERIOD}

This article investigates intimacy and sexuality among people in the late life period. The contemporary discourse on the subject of aging is based on the idea that, with age, all our abilities, desires and skills fade away. Aging is considered to be a form of failure and, in this regard, success is presented as the ability to conceal the signs of aging for as long as possible. The aim of this article is, firstly, to use theoretical approaches and empirical data to show why these views towards older people are incorrect. Secondly, this paper shows the necessity of doing social research able to understand the meaning and value given to sexual relationships by older people. Thirdly, the paper reveals the discourses and practices producing stereotypes that stigmatize and marginalize people in old age. In this research, we employ a constructivist approach to aging that views aging as a process constructed by social institutions. They ascribe certain norms of behavior such as ideas of success and failure. Conformity to these social expectations and categories is central to the construction of age. Empirical data collected during eighteen narrative interviews is used to demonstrate the inaccuracy of these views on the sexual and intimate life of the elderly. What is revealed are the problems that older people face due to inadequate and largely accepted views on meaning and value of sexuality in this period of life. Constructing older age by controlling sexuality and denying the right for sexual activity is another facet of sexism. Out research demonstrates that such practices (re)produce a discourse that marginalizes older people.

Key words: critical gerontology, sexuality in the late life period, narrative interview

DOI: $10.17323 / 727-0634-2018-16-1-125-140$

\section{References}

Carpenter L., DeLameter J. (eds.) (2012) Sex for Life: From Virginity to Viagra, How Sexuality Changes Throughout Our Lives. New York: New York University Press.

DeLamater J. (2012) Sexual Expression in Later Life: A Review and Synthesis. Journal of Sex Research, 49(2/3): 125-141.

DeLamater J., Koepsel E. (2015) Relationships and Sexual Expression in Later Life: A Biopsychosocial Perspective. Sexual and Relationship Therapy, 30 (1):37-59.

Estes C.L. (1999) Critical Gerontology and the New Political Economy of Aging. In M. Minkler, C.L. Estes (eds.) Critical Gerontology: Perspectives from Political and Moral Economy. New York: Baywood Publishing: 17-35.

Julia Zelikova - Assistant Professor Nord-West Institute of RANEPA, St. Petersburg, Russian Federation. Email: zelikova-ia@sziu.ranepa.ru 
Featherstone M., Wernick A. (eds.) (1995) Images of Ageing: Cultural Representations of Later Life. London: Routledge.

Galinsky A. M., Waite L. J. (2014) Sexual Activity and Psychological Health as Mediators of the Relationship between Physical Health and Marital Quality. Journals of Gerontology: Psychological Sciences and Social Sciences, 69B (3): 482-492.

Gledhill S., Schweitzer R. D. (2014) Sexual Desire, Erectile Dysfunction and the Biomedicalization of Sex in Older Heterosexual Men. Journal of Advanced Nursing, 70 (4): 894-903.

Gott M., Hinchliff S. (2003) Sex and Ageing: A Gendered Issue. In S. Arber, K. Davidson, J. Ginn (eds.) Gender and Ageing: New Directions. Buckingham: Open University Press: 63-78.

Gubrium J.F. (1993) Voice and Context in a New Gerontology. In T. Cole, W. A. Achenbaum, P. Jakobi, R. Kastenbaum (eds.) Voices and Visions of Aging: Toward a Critical Gerontology. New York: Springer: 46-64.

Hinchliff S., Gott M. (2017) Challenging Social Myths and Stereotypes of Women and Aging: Heterosexual Women Talk About Sex. Journal of Women and Aging, 20 (1): 65-81.

Karraker A., DeLamater J., Schwartz C. R. (2011) Sexual Frequency Decline from Midlife to Later Life. Journals of Gerontology: Psychological Sciences and Social Sciences, 66B (4): 502-512.

Kon I. (2005) Seksual'naya kul'tura v Rossii: Klubnichka na bereze [Sexual Culture in Russia: Strawberry on the Birch Tree]. Moscow: Iris-press.

Nizamova A. (2016) Aktivnoe dolgoletie i vneshnij vid: kak teoreticheskaja koncepcija reguliruet samovosprijatie v starshem vozraste? [Ageing and Outward Appearance: How Do Theoretical Conceptions Affect Self-Perception in Old Age?]. The Journal of Social Policy Studies, 14 (4): 569-582.

Phillipson C. (2006) Aging and Globalization: Issues for Critical Gerontology and Political Economy. In J. Baars, D. Dannefer, C. Phillipson, A. Walker (eds.) Globalization and Inequality. New York: Baywood Publishing: 43-58.

Rogozin D., Ipatova A. (eds.) (2016) Starikam tut mesto: sotsiologicheskoe osmyslenie stareniya [This Place is for Old People: Sociological Understanding of Aging]. Moscow: Institute of Sociology.

Sontag S. (1978) The Double Standards of Aging. V. Carver, P. Liddiard (eds.) An Ageing Population. Milton Keynes: Open University Press: 72-80.

Temkina A. (2008) Seksual'naya zhizn“ zhenshchiny: mezhdu podchineniem i svobodoy [Sexual Life of Woman: Between Subjection and Freedom]. St. Petersburg: European University at St. Petersburg Press.

Tetley J., Lee D. M., Nazroo J., Hinchlif S. (2017) Let's Talk about Sex - What do Older Men and Women Say about their Sexual Relations and Sexual Activities? A Qualitative Analysis of ELSA Wave 6 Data. Ageing \& Society, (4): 1-25.

Veenhoven R. (2000) Well-being in the Welfare State: Level not Higher, Distribution not more Equitable. Journal of Comparative Policy Analysis, (2): 91-125.

Vishnevskiy A. (2014) Smertnost v Rossii: Nesostoyavshayasya vtoraya epidemologicheskaya revolyutsiya [Mortality in Russia: Inconsistent Second Epidemiological Revolution]. Demograficheskoe Obozrenie [Demographic Review], 4 (1): 2-36.

Zdravomyslova E. A., Temkina A. A. (2000) Sociologija gendernyh otnoshenij i gendernyj pohod v sociologii [Sociology of Gender and the Gender Approach in Sociology]. Sociologicheskie issledovanija [Sociological Research], 12:33-46. 